Fences of Being: The Child in the World in Janet Frame's "A Note on the Russian War," "Prizes" and "Royal Icing"

\title{
Cindy Gabrielle
}

\section{CpenEdition}

\section{Journals}

Electronic version

URL: https://journals.openedition.org/ces/8172

DOI: $10.4000 /$ ces.8172

ISSN: 2534-6695

\section{Publisher}

SEPC (Société d'études des pays du Commonwealth)

\section{Printed version}

Date of publication: 1 April 2011

Number of pages: 110-123

ISSN: 2270-0633

\section{Electronic reference}

Cindy Gabrielle, "Fences of Being: The Child in the World in Janet Frame's "A Note on the Russian War," "Prizes" and "Royal Icing"', Commonwealth Essays and Studies [Online], 33.2 | 2011, Online since 18 November 2021, connection on 06 January 2022. URL: http://journals.openedition.org/ces/8172 ; DOI: https://doi.org/10.4000/ces.8172

\section{(c) $(1) \&$}

Commonwealth Essays and Studies is licensed under a Licence Creative Commons Attribution - Pas d'Utilisation Commerciale - Pas de Modification 4.0 International. 


\section{Fences of Being: The Child in the World in Janet Frame's "A Note on the Russian War," "Prizes" and "Royal Icing"}

By dint of a close reading of "A Note on the Russian War" (The Lagoon), "Prizes" and "Royal Icing" (The Reservoir), this essay examines what Janet Frame calls "a fence of being" in "A Note." In the Framean text, when individuals, especially children, surround themselves with fences of being, they renounce any true intimacy with other selves and with the real. Conversely, the absence of boundaries between one identity and the next or between the self and the world is not simply the condition known by deceased consciousnesses in Frame's haunting universe, for it is also the natural state of the human essence.

It has become customary in Janet Frame studies to emphasize the "superior knowledge or instinctive wisdom" (Bazin 24) enjoyed by children, and point to the disintegration thereof as concurrent with their imitation of adults' brand of conformism. In their careful readings of the author's early novels, the feminist critics Gina Mercer and Tessa Barringer have given these considerations a new twist: Barringer argues that the "entry into language and the social order," which occurs when the child-mother bond is disrupted, "deprives the child of her unique and individual voice, the voice of imagination and of dream, the unrestrained expression associated with the primal drives of Kristeva's semiotic" (71). Although Frame's texts indeed sustain that the child-figure's "instinctive wisdom" is superior to that of adults so long as it is unmediated by language and concepts - i.e. symbolic knowledge - I remain under the impression that establishing a strong equivalence between the nonconceptual order in Frame and a feminine realm of existence may at times prove rather misleading. Quite in the line of Barringer, Mercer indeed construes the "warm," "nurturing" and female-shaped "pockets, hollows, gaps and crevices" (39) in which children revel as the "source of life and creativity" (31), which she then opposes to the death-drive of contemporary culture. However, in dissociating the locus of creation from that of death and dissolution, it becomes almost inevitable to blend imagination with escapism, or the knack of preserving one's innocence in the face of the world's overwhelming darkness. My suggestion, therefore, is to think the nonconceptual otherwise, not in the light of feminist discourses, but as shaped by Frame's longstanding interest in Buddhist epistemology which, going beyond and encompassing the feminist linguistic approach, posits that the real in its utter complexities, with its intimations of life and of death, is the void of dissolution as it is empty of any permanent, and thence graspable, essence (Watts 42 ). ${ }^{1}$ Sharp as it may

1. Frame's interest in Buddhism is well recorded: she recalls in her Autobiography that she "had been studying Buddhism" as a student (156), and in her restricted circle of friends, many - i.e. Peter Elizabeth Dawson, Jim and Jacquie Baxter, Ruth Dallas, Charles Brasch - shared her interest in Buddhist thought. An entry in Charles Brasch's diary reads "Jim Jacquie [Baxter] \& Janet [Frame] to dinner. Talk mostly about meditation" (collected in Dear Charles Dear Janet, 20). As far as her fiction is concerned, her sixth novel, A State of Siege, echoes in many ways Evans-Wentz's The Tibetan Book of the Dead. The description of "The Clear Light" (the state of the non-ego) in The Tibetan Book of the Dead (97) and of the main protagonist reaching "first silence" (a condition of non-distinction) in A State of Siege (160) are remarkably close. What is more, the main protagonist's peregrination in the novel, as her consciousness is letting 
be, Buddhist wisdom explains, the knife of symbolic knowledge will never succeed in carving any form out of a reality that is shapeless as water, in which forms exist not in "their own right, but only in relation to one another" (Watts 41; see also Suzuki 21). To know the world, one must in fact discard the kind of discriminating consciousness that endeavours to "grasp the fluid forms of nature in its mesh of fixed classes" (Watts 42) and plunge instead into the void, something which, as we will see, the author's characters and her critics often misconstrue as a death sentence.

The tendency displayed by Frame's critics to dismiss children's awareness of death can be traced back to Patrick Evans to whom the "pattern in which images of a happy and secure childhood [recede] momentarily to admit a terrifying image of the pain of adult life, dominates nearly all the stories in The Lagoon" (40). The absolute bleakness of the outcome, Evans goes on, makes way for a more positive alternative in "A Note on the Russian War" (in The Lagoon), a rather mysterious tale focusing on a family playing in their garden, sunflowers, living in Russia and the outbreak of a war - hence perhaps Ian Richards' contentious comment that the text "reads as something incoherent, the product of a troubled author" (126). To Evans, "A Note on the Russian War" represents an "important development in Janet Frame's art" in that it exemplifies that the means of escape from the "harsh and unpleasant world" of adults lies "within the self, the individual world of insight and imagination" (Evans 44). Richards makes a similar point in arguing that the mother holding a sunflower in her hand and repeating that "we are Russian because we have this sunflower in the garden" (Lagoon 151) must necessarily appear as childish to the reader as it is "the behaviour of an innocent" (Richards 128). Contrary to Evans, Richards invests "the essentially abstract, escapist pleasure offered by sunflowers as catalyst for imagination" with a negative significance and concludes that the children should offer "resistance to the power of imaginative capture exercised by the mother" (Richards 131) to grow up and face the real world. Notwithstanding their divergence of opinion as to the moral value of imagination, both critics are in essence situating the mainspring of children's creativity in their denial of the world's darkness.

The irony, however, is that a close reading of the text would reveal that the sunflower is less a springboard for any escapist drive than an earthly avatar of the natural which in Frame is always instrumental in breaching human fortresses of selves, and is thus perceived as the enemy itself. Retrenched behind their castle of identities, armoured personalities indeed frequently find themselves besieged by inconvenient memories or abstractions such as time and death, or by other selves and by the natural. This is very much the informing principle of, among other texts, "A Night of Frost and a Morning of Mist" (in Snowman), where a tomcat and a blowfly that embody "the armies of life and death which emerge with the sun, from a night of frost and a morning of mist" (Snowman 108) are clamouring for some sort of entry in an unyielding narrator's mental and actual abode. ${ }^{2}$ Several of Frame's short stories thus point to the fact that all trespassers, and so the sunflowers, are more often than not treated as enemies to be vanquished. The juxtaposition of the extremities of "A

go of life, corresponds in many ways to the deceased traversing different after-death planes in The Tibetan Book of the Dead.

2. Other texts that centre on similar intrusions are for instance "A Windy Day" and "Visitors from the Fields" (also in Snowman, Snowman), and A State of Siege. 
Note" provides an alternative point of entry to the tale that suggests a similar conclusion:

The sunflowers got us, the black seeds stuck in our hair, my mother went about saying in a high voice like the wind, sunflowers kiddies, ah sunflowers. (Lagoon 151)

We were just Russian children on the Steppes, singing tra-tra-tra, quietly with our mother and father, but war comes whatever you sing. (153)

The narrator's claim that "the sunflowers got us" not only alludes to the fact that "A Note" focuses, literally, on a garden war, ${ }^{3}$ but it also carries a hint that the safety enjoyed by the family at the close of the tale is relative since the threat of invasion is actualized in the opening lines; as the narrator concludes, "war comes whatever you sing."

Quite in keeping with this, the child-narrator in "A Note" had foreseen that the "war rolling through the grass" would be "something about sunflowers and a tall sky" (Lagoon 151). The uncanny dangerousness of the plant may very well reside in its endemic multiplication, conveyed in the subtle shift in emphasis from the assertion that "we are Russian because we have this sunflower in the garden" (152) to the hint that "in the Russian War [...] [w]e had sunflowers by the fence" (152). ${ }^{4}$ Poised on the family's garden fence, the symbol par excellence of the border between one's territory (of self) and the remainder of the world, the flowers launch their offensive and this is why "out of the spring and summer days the War came. An ordinary war like the Hundred Years or the Wars of the Roses or the Great War where my father went and sang Tipperary" (152, emphasis mine). Thus, at a deeper level of interpretation, "A Note" encodes a concern with a self-consolidating epistemology and ontology centred on violence and which accounts for the fact that even the multiplication of a flower is seen as a declaration of war. ${ }^{5}$ For all their presumed innocence, the children are wellprepared for the battle as they have trained to "[stick their] teeth through the bitter stems" of flowers (152) and sing "tra-tra-tra" (153), in tune with their mother and father, to cover up their mounting fear. If the first sentence in the tale - "The sunflowers got us" (152) - indeed is an anachronistic intimation of "defeat," it also carries a suggestion that the mother has thrust aside her initial terror at the prospect of the invasion. She cries out in delight "sunflowers kiddies, ah sunflowers" (152) as she now relishes the presence of the trespassers. Her welcoming stance may very well be fuelled by a disavowal of sorts of the frontiers erected between the "same" and the "foreign," the "self" and the "other" or "enemy" which, she deems, are human inventions. She strikes a lyrical note when she explains to her children that "there are no lands outside, they are fenced inside us, a fence of being and we are the world" (152). "What the mother is saying in a nutshell is that "New Zealand" or "Russia" are

3. For a further discussion of Frame's literal use of language, see Marc Delrez's article in the same volume.

4. Frame similarly anthropomorphizes plants in an essay called "Departures and Returns," when she explains that, though the roots of the fig tree (the poet) "go deep," the plant is nonetheless capable of "invad[ing] territory where it's not welcome, and then it is cut down, killed in spite of its fruit" (91).

5. For a further discussion on the universalizing of the theme of war to domestic circumstances, see Marc Delrez's "Conquest of Surfaces," 139.

6. Aptly in a text that defends the deterritorialization of selves, the narrator's voice is hardly distinguishable from that of her mother. It may very well be, then, that the assertion that "there are no lands outside, they are fenced inside us, a fence of being and we are the world" stems from both consciousnesses. To complicate matters further, this process of deterritorialization is horizontal as well as vertical for it occurs "in space and time" (151, emphasis mine). 
but concepts that become meaningless once outside the symbolic order. However, to uncover the full complexities of this seemingly stale assertion, one must seek a ground of exploration other than the western "pure" linguistic perspective and approach it instead within the ambit of Buddhist wisdom with its emphasis on the non-dual nature of concrete reality (see Conze 171).

While Buddhism sees the world as made up of elements and events that are devoid of clear boundaries, ${ }^{7}$ formal knowledge has devised sealed classes to apprehend the real and "insists that life [should] be bound and fitted to its rigid categories" (Watts 19). Thus, although "the reality of all inseparable opposites" is "that 'between' for which we have no words" (Watts 121), the mind that relies on dualisms dichotomizes occurrences such as beginning and end or life and death, stone beings and creatures of flesh, men and women, adults and children, and usually values one of the terms of each antinomy above the other. To Frame, it is precisely this hierarchization of the living and of the inanimate which paves the way for egotistical conflicts, as though the locus of war was indeed to be situated in the realm of the symbolic. Not only is a logic of exclusion driven ad absurdum perfectly represented in the parallel that is made between historical and garden wars in "A Note," but the text also intimates that the territorialization of selves by such concepts - when they are "fenced inside us, a fence of being" (Lagoon 151-152) - has dire ontological consequences as well. In accord with the Buddhist perception that we have "no other selves than the totality of things of which [we] are aware" (Watts 120), characters in Frame are the world, yet they cease to be at one with it when they call upon those spurious fences of being and decide to exist only in the realm of the symbolic. A contrario, the characters who seek to alleviate their ontological homelessness constantly probe beyond the words and this is why, true to her conviction, the mother transports herself and her children, imaginatively, to Russia. Far from testifying to a longing for escape, imagination is a means of crossing over the dark portals of life towards territories so far uncharted. This can be seen to concur with the hypothesis that in smothering their imagination, the childcharacters' birth in the symbolic also endangers their peculiar brand of belonging in the world.

If enlightenment or Satori in Zen Buddhism "consists in reaching the point where all our discriminatory notions are done away with," where "a new world hitherto unperceived in the confusion of a dualistic mind" begins to unfold (Suzuki 89, 58), children in Frame could be said to go through what may be termed by analogy a "counter-satori experience," an enlightenment in reverse whereby one's total awareness

\footnotetext{
This undoubtedly explains the kind of commuting between past and present that is perhaps conveyed in the now adult narrator's assertion that she will "never forget being in Russia" (151).

7. As Suzuki explains, "all things have the character of emptiness, they have no beginning, no end, they are faultless and not faultless, they are not perfect and not imperfect" (Suzuki 21). On the face of it, Buddhism emerges as a mode of knowledge which opposes the rigid dualities that are central to Platonism for instance. Thus, even though there exist some affinities between the Buddhist and the Platonist approaches to Frame insofar as both philosophies posit that, to paraphrase Jan Cronin, "man remains trapped in the realm of the shadow" (Cronin 15), probing beyond these shadows is according to Platonist discourses impossible given that the un-obscured sphere of existence is located outside our everyday reality (see Cronin 15). Buddhism, by contrast, trusts that the individual can escape from the entrapment of shadows if $\mathrm{s} /$ he ceases only to be "clouded" by preconceived ideas about what the real should be. Because the un-obscured sphere of experience is simply a reality which is not territorialized by ideas of, for instance, perfection and imperfection and which, as a result, is of this world, the blockage of human perceptions is by no means final in Buddhism.
} 
of life is discarded in favour of a discriminating consciousness. Fences of being, the bearings which define identities and provide individuals with a spurious sense of protection, are a key notion in the Framean text and shall be my point of entry into two neighbouring tales in The Reservoir, "Prizes" and "Royal Icing." I will show that the territorialization of being conditions the extraction of children from the pre-symbolic order and thwarts their (re-)entry into what Frame variously calls the "area of universal belonging" (Siege, 186), the "common pool" (Intensive Care 13), or the "huddle" ("Prizes" Reservoir, 19). My intention in what follows is to collapse the distinction between the a-symbolic vista of children revelling in the "huddle," and the utopian condition of shared being identities know in the "common pool," the latter of which has tended to be defined not merely as a creative selflessness (a feature the pool shares with the huddle) but also as a post-mortem fate (see Delbaere-Garant 153 and Delrez 98). ${ }^{8}$ In accordance with Frame's description of these orders of reality in "Prizes," I shall refer to the locus of separate identities as "the pit" and to its perfect antithesis as the "huddle." I will show that if the real is a plane of existence which remains untouched by symbolic knowledge, unadulterated by discriminating egos, and if it may be experienced not just by the dead but by children for instance, it entails that the huddle is not to be located exclusively in "that" world beyond disintegration, for it also belongs to "this" world of the living.

Even though I have warned against constructing innocence as a death-free zone, I nonetheless agree with Evans and Richards that the author's short stories and early novels abound in tales of threatened childhood and lost Edens. That adulthood by contrast should be seen as a fallen state is sustained in Owls Do Cry but also, perhaps even more explicitly, in "Prizes" where "dark sneaks in" ("Swans" Lagoon, 64) just when the child-protagonist develops a porousness not to (pace Evans and Richards) the realities of death, but to consensus thinking. Appropriately enough, the tale opens with the narrator's lament that her childhood should have been turned into a painful plucking, feather by feather, of her angel's wings:

Life is hell but at least there are prizes. Or so one thought. One knew of the pit ahead, of the grownups lying there rewarded, arranged, and faded, who were so long ago bright as poppies. One learned to take one's own deserved place on the edge, ready to leap, not to hang back in a status-free huddle where bodies were warm together and the future darkness seemed less frightening. Therefore, one learned to win prizes, to be surrounded in sleep by a dream of ordinal numbers. ("Prizes" Reservoir, 19)

Keen on demonstrating the extent to which her former self used to be convinced that prizes could be a solace for living in hell, the narrator meticulously catalogues, throughout the tale, her "share of prizes, and of resentment when nobody recognized [her] efforts" (19). Also, she recounts with some guilt how, engrossed in the knowledge of her academic superiority, she often derided the "stodgiest" (23) or most unpopular pupils in the class, following in fact her teachers' example. Unsurprisingly the long list of prizes overlapping for a great part with details from Frame's autobiography has prompted some to read the story as the author's tribute to the

8. We will see that, in the huddle, children know a condition of selflessness that is also typical of death since death is the ultimate state of undifferentiatedness. To complicate the matter further, however, the individuals in the pit, because they are reluctant to endorse such a condition of non-being (unlike children and the dead), are seen to be dead, not literally so, but on a spiritual level. 
nascence of her artistic self. ${ }^{9}$ Indeed, in calling a 2009 volume of Frame's selected stories Prizes, ${ }^{10}$ its editors clearly state that they too acknowledge her artistic gift. Celebrating the writer in such a fashion is, however, highly ironical since the short story itself relentlessly condemns the hierarchization of selves that underpins the search for, or the granting of, prizes - even literary ones.

Critics have often noted that the endorsement of materialist values condemns the individual to a sluggish existence in Janet Frame's texts, ${ }^{11}$ yet very few have delved into the raison d'etre of this notion in connection to the author's concern with human existential loneliness and incompleteness. Indeed, the dream of ordinal numbers which, in the quoted passage, cuts through all entanglements with individuals in the huddle is but a manifestation of those fences of being that separate the knower from the known and create a no-man's land between one self and the other. Intrigued by the nature of children, the narrator in "Jan Godfrey" crucially intuits that the individuals caracoling in the huddle (here the big playground) are unable to locate the boundaries of their identities and therefore know a condition of selflessness:

We cling to our names because we think they emphasise our separateness and completeness and importance, but deep down we know that we are neither separate nor complete nor very important, nor are we terribly happy (Alison Hendry, Margaret Burt, Nancy Smith, children) playing mud-pies by ourselves in a tiny backyard when other kids are out in the big playground over the fence, look what I've made, race you Charlie, tell tale tit your tongue shall be split and all the little puppy dogs shall come and have a bit.

You can tell that the kids in the playground haven't got names. (Lagoon 131)

Having little interest in the symbolic, the children in the big playground do not resort to strategies of self-definition by means of exclusion and feel free, on that account, not to emphasize their separateness by playing mud-pies on their own. The tiny backyard in which children learn to nurse their individuality in "Jan Godfrey" qualifies in this context as a variant of the pit in "Prizes" which, though it is the abode of countless individuals, allows no transactions between selves. These considerations not only carry a hint that the shortcoming of prizes, names and other symbolic fences is to be ascribed to their potential for division but also that the process of individuation whereby children territorialize their selves is nothing other than the fall into the pit, a hellish place where what you are belongs to you alone. If the pit indeed is the area of universal nonbelonging, the upshot is that the process of individuation must necessarily be seen as a satori in reverse and a spiritual regression of the gravest kind.

The move from huddle to pit, from the locus of dissolution to that of selfcontained identities, is a descent into loneliness which is eventually upheld tooth and nail out of a belief that the dissolution of the discriminating ego is not a melting into life but a death sentence. This approach, which incidentally runs counter to the

9. One thinks most notably of the guinea which Janet spent on piano lessons in the chapter of the autobiography entitled "Faust and The Piano" (105-109).

10. One of the reviewers says for instance that "the title story is not about simple triumph, but a sharply satiric account of a young girl whose excellence is clawed away from her by the steady efforts of mediocre and conformist rivals" (see Murray Bramwell on http://www.nzbooks.org.nz/la testeditorial.html).

11. See for instance Patrick Evans, Janet Frame or Anna Rutherford, "Janet Frame's Divided and Distinguished Worlds." 
Buddhist understanding of selflessness, is typically that of the narrators' parents in "Royal Icing" who consider life as a "slowly closing wound where the edges must be prevented at all costs from uniting" (Reservoir 40). This, in turn, prompts their daughter to link her parents' yearning for material possessions which they cannot afford with their fear for sealed edges, as though dreams could be "wedge[d] between birth and death" to "stretch life, like a tightening shoe, to make it fit for ever and ever" (40). Year after year, when the mother ices the cake for Christmas, both parents agree that:

"We need a set of those things, you know, they use them for icing cakes."

"One of these days," my mother said. "We never know, do we, one of these days?"

"Who knows?" my father said.

That was a mysterious conversation. (34)

Eventually, the "set of icing-forcers" (38) is purchased, yet it is never put to use and is placed instead "beside the few pieces of china which were too good to be used" (39), where it becomes "a landmark on the sideboard" (40). It is interesting to note here that the china cup, plate and saucer have been offered by the narrator in "Prizes" to her mother with the prize-money she earned for some poems; a link which vindicates the approach to "Royal Icing" as a continuation of "Prizes." Locking up the china dishes in the cupboard, the mother declares that she is "keeping the set for when she could really use it" (21). Sadly, she dies before finding an occasion grand (or Royal) enough to eat from her daughter's six-and-fourpenny gift to her. Thus, the unnecessary complication between "using something and really using it" (21) hinted at in "Prizes" is further examined in "Royal Icing" where, as we are going to see, it evidences a half-acceptance and, in fine, also a half-rejection of overflowing boundaries on the mother's part.

The various threads traversing these two neighbouring tales curiously converge in the image of the iced cake which, as the following passage illustrates, has been topped with more than one layer of significance so that, clearly, Frame is having her cake and eating it:

[M] y mother continued icing the cake [the old way], dipping the knife in hot water and spreading, coaxing, trying not to mind when the stuff ran down the sides and the pink icing flowed into the white.

And so our lives continued and we did not think that fact mysterious because we expected it; aunts, uncles, grandparents, people over the road or in the next street were for dying in the end but we were for being alive; with so many fat spaniel dogs lying down in the corner of the washhouse to have puppies, we had no choice.

The fleas were such a worry. What if they spread to the neighbors? (34-35)

That, in the absence of an icing forcer, the pink and the white icing fail to keep to their assigned places on the cake can be seen to illustrate that the boundary between living and dying is not as definite as the parents would like it to be. Likewise, fleas or, for that matter, sunflowers know no frontiers and may spread to the neighbours or encroach on one's private territory. To those who, like the protagonist's parents, assume that dying is akin to a union of edges, these invasions or moments of overflowing are surely so many intimations of mortality so that, in retrospect, it becomes possible to infer that adults "share the pit, each in her [or his] assigned place" (23) precisely because they have grown distrustful of huddles where identities have no clear boundaries, a state which they now assimilate with the utter physical 
disintegration that coincides with death. In this sense, "the adroit targeting of an icing forcer" (37) can prove a useful ally in the struggle against reunification: "they're like guns," pronounces an awed mother, "you can use them for shooting out biscuit dough into any shape you want" (35).

Ultimately, then, the baker's utensil must be added to the already long list of icepicks, scissors, knives and axes with which human beings carve the rims of their identities. Interestingly, this can be seen to invalidate the narrator's final assertion that the desire to possess is a form of escapism, aimed at shunning the knowledge that death is looming close:

Tell me, what do we need? What dream must we pursue and not be afraid to grasp and possess when it finally becomes reality? Is it better to want and get an icing forcer, a mincer, than to walk for the remainder of our lives about the house with a little dagger in our pocket trying to catch Death bending over the coal in the coal house or tying up the stray broad beans or sweet peas on the trellis, or sitting in the sun snoring? Trying to catch and kill him, and then with a surprised look on our face, turning the dagger to our own heart? (40)

What the narrator cannot quite comprehend is that the icing set, in its capacity as an instrument of separation, perfectly equips the numerous individuals who deceive themselves into thinking that mortality can be stabbed to death. Quite in the same line, there is a definite suggestion in the text that the accumulation and use of objects of prestige in a household has to be underpinned by an impulse to fight death given that disintegration by decay is also the enemy of inanimate objects. The icing-forcers must be cleaned thoroughly after use, insists the father repeatedly, "we don't want them to get rusty, like the mincer, or stuck with scum, like the separator" (38). Thus, whoever owns an icing set has the responsibility of "perform[ing] the agility known as "coping," which the narrator takes to mean "creeping up to one's enemies, unsuspected, and enveloping them in a dark cloth, perhaps smothering them" (38). In the last analysis, then, Frame may be indicting the attachment to material goods fitted with guns, smothering bags or daggers as part of yet a larger, more disturbing tendency in human beings to keep otherness at bay through the compartmentalization of selves.

I wish to argue at this juncture that the distinction that is drawn between the endorsement of materialist values and the lucid acknowledgement of mortality is as spurious as the gulf supposedly separating birth and death, the edges of the wound. Therefore, what the mother perceives when she sees death "bending over the coal in the coal house or [...] tying up the broad beans and the sweet peas that had strayed from the trellis" (40) is a mirror image of herself performing these daily chores. Death is, in other words, no external threat but a growth of darkness each living creature accommodates internally and this is why, when we try to "catch and kill him," we realize with a "surprised look that" we have turned the dagger "to our own heart" (40). As such, the statement made in "Royal Icing" that death is indestructible is something of a truism, unless one is to keep in mind that death is an overflowing of artificial boundaries, described in Daughter Buffalo as the turning point when the self fails to "control its natural impulse to flow" and "the one, no longer self-contained, [becomes] the many" (106). Again, though, one should not conclude from this that the "unfencing" of the self or the relinquishing of exclusionary protocols of 
knowledge is, by contrast, necessarily lethal. In The Carpathians, for instance, survival is equated "with maintaining point of view, indeed with being as a point of view" ("Note," n.p.) so that, when Mattina's viewpoint is robbed by an imposter novelist for a quarter of the novel, her very life threatens to disintegrate into nothingness. Yet she eventually emerges from the parenthesis in which she was maintained quite safely. ${ }^{12}$ To complicate things further, death is not always made apposite to the dissolution of the controlling ego: in "Snowman, Snowman" and in A State of Siege, Rosemary Dincer and Malfred Signal are both made to accommodate the real after their death in the sense that they respectively suffer the invasion of scurrying insects and of a storm which, in gnawing through skins, walls, windows and other boundaries, allow at last what had been kept outside and rejected as "other" to flow inside. ${ }^{13}$ At any rate, suffice it to say by this point that "A Note on the Russian War" and "Royal Icing" but also, as we shall see, "Prizes," sustain that overflowings and invasions are as inevitable as they are natural and that, no matter how dutifully adults stand in their assigned places in the pit, the natural world, other selves and death will intrude, for "war comes whatever you sing" ("A Note" Lagoon, 153).

If this fluidity, the kind of undifferentiatedness which human beings experience in death or, crucially, in the status-free huddle, is indeed the true nature of the human essence - and this must be taken to mean that human beings have no individual essence or self-nature since they are the world - then the path leading to authenticity involves either progressing forward towards utter or spiritual disintegration or backwards to a womb-like state. In this case, the image of the overflowing icing may very well be a metaphor for the human essence when, prior to the violent meddling of the icing-forcers, it interpenetrates with other selves. In "Prizes" it is acknowledged that individuals are in part responsible for their fall into the pit, yet attention is also called to the fact that children learn to take their deserved place on its edge, ready to leap. And, since this learning is fraught with violence, it is by internalizing the violence deployed to march individuals to their assigned places that children serve the status quo. For her part, the narrator comes to understand this when, during one of her return trips to the town of her childhood, she comes across two of the girls whom she used to scorn. They have become beautiful women, whirling in prams their "cocooned, quilted, embroidered treasure" (Reservoir 23). And she, who is twenty-five years old and childless, realizes how miserable she must appear wearing a "dirty old gabardine" and "dowdy clothes" (23):

They smiled at me and I smiled at them. We shared the pit, each in her place. The rain poured upon the bed of crushed poppies between us. Yet the delicacy and distance of the two women were unmistakable; I grudged their proud cloaks as they trooped, clients of love, on their specially reserved side of the world. (23)

That the bed of poppies has been trampled on perhaps by trooping individuals prone to defend their reserved side of the world obliquely alludes to the violence with

12. For a further discussion of this topic, see my article entitled "The Poetics of Dissolution: The Representation of Maori Culture in Janet Frame's Fiction,” Journal of Postcolonial Writing 46.2 (May 2010): 209-220.

13. In this, Frame's poetics can be seen once to bear some similarities to Buddhism (more particularly in this case, to its Tibetan form) where death is seen as an intermediary stage where identification is still possible and may or may not be renounced after a length of time which varies according to individuals (see Conze 221-236). It could be argued in this context that Malfred's last round of identification in A State of Siege, before she lets go of her discriminating consciousness, takes place six months after her death. 
which adults, "who were so long ago bright as poppies," were compelled to lie in a pit "rewarded, arranged, and faded" (19). Through the juxtaposition of metaphor (the pit) with simile ("bright as poppies"), Frame is intimating that the self lies in a vault awaiting either its death or, Juliet-like, some kind of rebirth once it has been plucked from the natural.

While it must be admitted that the loss which becoming adult implies seems irremediable, some provision is nonetheless made in the tale for a possible resistance against society's Procrustean treatment. The children in Onui for instance are all intent on entering a buttonhole for the flower display, so much so that one morning they are rebuked by a "militant woman" who, in a speech, "accused too many people of entering for the Buttonhole Section [...] as [buttonholes] were an art beyond our years that even grownups found difficult to master" (20). The narrator remembers that she nevertheless persisted year after year in competing for the first, second or third prize of the flower display. In this particular instance, the child's keenness for prizes denotes at once an acceptance of a world order based on division and categorization, and an unwillingness to compete in the category which befits her station in life. Significantly, she crosses over usual boundaries and resists the militant woman by "surrender[ing] her exhibit" (20). The child's act of non-violent resistance prefigures in an important sense her ultimate disengagement from the conquering armies trooping on the earth, to which she will surrender. Her growth of understanding occurs when she purchases her first piece of music but happens to run across her piano teacher who guesses the girl's pleasure. Having seized "a momentary aspect of [her pupil's] behaviour," Hessie Sutton begins to "[honk] with triumph like the soldier who brought back the golden horn from the underworld" (26). Infuriated by her piano teacher's "superior parading of the victorious" (23), the child realizes that:

People were saying, observing me closely, "She's filling out, she's growing tall, look at her hair, isn't that Grace's chin she's got, and there's no doubting where her smile comes from!" You see how derivative I was made out to be? Nothing belonged to me, not even my body, and now with Hessie Sutton and her spying ways I could not call my feelings my own. Why did people have so much need to stake their claim in other people? Were they scared of the bailiffs' arriving in their houses? I stopped learning music. I was in despair. I could no longer use prizes as a fortress. In spite of my book bound in calf [...] and my marks of merit in the children's newspaper, I was being invaded by people who wanted their prizes from me. (26)

Instead of sharing her pupil's excitement about buying her first music piece, the teacher snatches it from her, leaving the girl bereaved and angry. Quite in keeping with the idea that conquest prevails over communions of I's in the adult world order, the only exchanges that take place between selves are anything but reciprocal and consist rather in mere appropriations, where the riches of someone's essence are plundered by another self. ${ }^{14}$ At first, it may seem that the child is being invaded because she has renounced using prizes as a fortress equipped for defence and retaliation. However, it is clear that she is invaded in spite of them by Hessie Sutton and the likes and therefore she wakens from the illusion that division equals

14. In my article "The Poetics of Dissolution: The Representation of Maori Culture in Janet Frame's Fiction," the phrase "staking a claim" which often recurs in Frame's texts is examined in some details and it is concluded that, more often than not, to stake one's claim in the real (for instance in Maori culture) is to try and appropriate it. 
protection. The supreme irony in the Framean text is that, having rejected the natural overflowing of their essence with that of the living and of the dead, human beings fall prey to another kind of invasion (by predatory teachers and greedy relatives) which is far worse because it is no longer based on the language of communion, on the principle of reciprocity that governs the nonconceptual reality of the huddle. Therefore, human beings lie in the pit, "robbed of all prizes, while still under every human sky the crows wheel and swoop, dividing, dividing the spoils of the dead" ("Prizes" Reservoir, 26).

To express, perhaps, a recovered faith in the fluidity of a real that contains intrinsically no palpable boundaries or separated essences, the narrator in "Prizes" dismantles the barriers isolating her self and, to me, this crucial move is a clue that authenticity in Frame is to be measured in terms of renunciation. A similar deterritorialization of being allows the family in "A Note on the Russian War" to say that "we are Russian because we have this sunflower in the garden" (Lagoon 152). The impending invasion, on the other hand, perhaps prompts them to reassemble the discarded fences by intoning war tunes for, in the fashion of the soldiers in the Great War where the "father went and sang Tipperary" (152), the children sing "tra-tra-tra, quietly, with [their] mother and father" (153). Clearly, securing fences of beings partakes of an imperialist impulse which, in "A Note on the Russian War" and "Royal Icing," tends to be associated with the masculine. In "Royal Icing," the father wages a war against fleas, the symbolic counterparts of the fluid icing, and "leap[s] up and down at all hours crying, 'Got one, Got one, Hear them Crack?"' (Reservoir 34). In "creeping up to [his] enemies, unsuspected," the father can be said to perform "the agility known as coping" (38). And when this agility is related to the cleaning of the icing set, which must not go to rack and ruin lest it should lose its separating power, it becomes clear that those who cope and clean pledge allegiance to a world order based on division. It is no wonder, then, that the father often chants: "I'd rather have a hardboiled egg" (35), proclaiming his preference for fixed categories.

The mother, for her part, finds that responsibility is a "terrible substance to be apportioned and mostly it came to rest upon the government, but the atmosphere could accept it just as well" (33). In other words, she distributes blame rather randomly in the manner that the mother-figure in "Prizes" has also adopted, "in exasperation, when she was pestered for raisins, dates or the last of the chocolate biscuits" ("Prizes" Reservoir, 22). The former's daughter finds this a positive failure and wishes that schools would distribute prizes in such a fashion instead of singling out a few pupils for praise. My impression is that the mother-figure's inability to select, and thus to exclude, possibly lifts a corner of the veil on a distrust for a reality that would not be complete, which she may be hinting at in "Icing" when she exclaims in horror: "never drink skim-milk" (36). What is more, she is a poor housekeeper with a "natural difficulty in coping" (38). By this token, she deems that the baker's set is "too good to be used" (39) and prefers icing the cake the old way. The mother's particular brand of materialism therefore is purely abstract so that, in losing their status as unattainable dreams to assume that of actual weapons obliging one to "cope," objects become an embarrassment to her. In conferring on such weapons the mere function of landmarks or collectibles, she clearly unloads the guns' lethal cargoes. The motherfigure, in other words, responds to violence with intimations of peace and emerges in 
this respect as the alter-ego of the mother-figure in Owls Do Cry, "whose attributes as a peacemaker are the pikelet and cup of tea, which are infallible, she finds, for settling arguments and family feuds" (Delrez Utopia, 19). Aptly, the overflowing icing in the short story forms a counterpart to the criss-cross patterns with which Amy decorates her own cakes in the novel, something which has prompted Marc Delrez to conclude that "the priestess of redemption is not the 'mad' Daphne alone, but also her mother Amy" (19). Thus, from The Lagoon, through Owls Do Cry down to The Reservoir, mother-figures disavow fences of being for they intuit that "being alive is tangled" (Owls 45). While I do not wish to deny that the peacemaking mother-figure sometimes ambivalently longs for cleanliness and deathlessness to escape from the fearful muddle of life, she nonetheless must be seen to rank amongst Frame's most positive characters. Thus, Delrez is right to assert that the mother's authenticity resides in her sense of a close-knit community but at a further remove, it seems to me that her inability to disentangle, select, clean or cope, sometimes aligned with a certain atoneness with the world, ${ }^{15}$ reveals her proximity with the original state of the human essence: its nonexistence. Indeed, the absence of division and categorization, the impossibility of retaining an identity or essence apart from the real, is above all the governing principle of the status-free huddle, in contradistinction with the pit.

In this essay, I have attempted to demonstrate that, far from being curved into circularity beyond the edges of life, when the move from the "first place of fluid darkness" (Frame Autobiography, 7) and back again is at last complete, human destiny is inscribed within the void of dissolution. Death or fluidity, in other words, is not merely inherent in the human existence but is the human essence. We have seen in "Prizes" and "Royal Icing" that the accumulation of prizes and objects of prestige stem in fact from a desire to maintain some form of distance from other selves and from death which, however, exists internally. As it allows the knower to separate herself or himself from the known, the hierarchization of experience paves the way for the violence known as "coping" by virtue of which dichotomous values (one country versus another, the human versus the natural) are enforced. This, in turn, may be seen to show that reaching the nonverbal, concrete world involves on the part of authenticity seekers a great deal of passivity, an unwillingness to use symbols to target and exclude foreign bodies from their invasion-proof organisms. All this may touch upon a crucial aspect of Frame's poetics for, if the fences of being that are erected around the self are constituted by names, tokens of prestige and other such emblems, this implies in an important sense that, to exist in all worlds as an "unfenced" and "deterritorialized" being, is to discard the symbolic.

Indirectly perhaps, the difficulty of doing so is intimated in "Jan Godfrey" where names are said to be mostly useful for individuals eager to insist on their separateness, which may indeed be taken to indicate that identity - or at least the discriminating ego - is an arbitrary symbol, a fence of being. This no doubt explains why the process of individuation that is associated with becoming an adult in "Prizes" is a descent into a hellish pit where consciousness becomes stationary, and imaginative transport to Russia or to any other country becomes unthinkable. In fact, stationary

15. One thinks for instance of the short story "Swans," in The Lagoon, in which the mother knows about the natural world and about death but becomes very awkward when it comes to "coping" with sad news. 
consciousnesses are altogether unable to probe beyond their own backyard or temporary vault, of which the one tragically constant feature is the way it stays permanent (to paraphrase Frame's A State of Siege, 167). At any rate, the point here is that the most trenchant weapon of exclusion may well be the blade of identity. This is not to assert once more that "man can become his authentic self [if] he accepts the boundaries of his identity as 'a temporary token agreement' of which he tries to make the most before merging into the great undifferentiated whole" (Delbaere-Garant 153) by dying. Janet Frame would be very pessimistic, to say the least, if she provided no grounds for evolution in her texts, if the counter-satori or enlightenment in reverse that is forced upon children were never to be compensated for at all by a genuine satori experience. Therefore, the redemptive potential of the achievements of children and mother-figures who, in "Prizes," "Royal-Icing" and "A Note on the Russian War," all wave a white flag above their heads, is not to be underestimated. "Prizes" and "Jan Godfrey" further make some provision for a more optimistic reading of Frame's poetics of dissolution in their intimations that, in the huddle, children perhaps know a state of selflessness, yet they are still alive and functioning. Not only is surrendering one's identity prior to death possible and desirable as it is a means of accommodating otherness, but it is also an artist's duty for, as the author-figure says in Living in the Maniototo, "to write you have to be at the terrible point of loss" (72). Death may be a gateway to being for Janet Frame, but "negative capability" is another

\section{Cindy GABRIELLE, University of Liège}

\section{Works Cited}

BARRINGER, Tessa. "Powers of Speech and Silence." Journal of New Zealand Literature 11 (1993): 71 88.

BAzIN, Claire. "Janet Frame: 'Keel and Kool' or Autobiogra/fiction." Commonwealth Essays and Studies 29.2 (Spring 2007): 19-28.

Bramwell, Murray. "Frame, Prizes: Selected Short Stories; Witi Ihimaera, His Best Stories; Owen Marshall (ed), Essential New Zealand Short Stories." New Zealand Books: A Quarterly Review 19:3 (2009). Extract available on http://www.nzbooks.org.nz/latesteditorial.html. Accessed on 25 April 2010.

ConZE, Edward. Buddhist Scriptures. London: Penguin Books, 1959.

Cronin, Jan. "Through a Glass Darkly: Reading the Enigmatic Frame." Frameworks: Contemporary Criticism on Janet Frame. Ed. Jan Cronin and Simone Drichel. Amsterdam \& New York: Rodopi, 2009. 3-23.

Delbaere-Garant, Jeanne. "Death as the Gateway to Being in Janet Frame's Novels." Commonwealth Literature and the Modern World. Ed. Hena Maes-Jelinek. Liège: Marcel Didier, 1975.

DelREZ, Marc. "Conquest of Surfaces: Aesthetic and Political Violence in the Work of Janet Frame." Frameworks: Contemporary Criticism on Janet Frame. Ed. Jan Cronin and Simone Drichel. Amsterdam \& New York: Rodopi, 2009. 135-153.

-. Manifold Utopia. The Novels of Janet Frame. Amsterdam \& New York: Rodopi, 2002.

Evans, Patrick. Janet Frame. Boston: Twayne Publishers, 1977.

Evans-Wentz, W.Y., ed. The Tibetan Book of the Dead or the After-death Experiences on the Bardo Plane. According to Lāma Kazi Dawa-Samdup's English rendering. Psychological commentary by C. G. Jung, introductory foreword by Lāma Anagarika Govinda, foreword by Sir John Woodroffe. London \& New York: Oxford University Press, 1957.

Frame, Janet. An Autobiography. 1989. New York: George Braziller, 1991.

—. The Carpathians. New York: George Braziller, 1988.

—. Daughter Buffalo. 1972. New York: George Braziller, 1992.

—. "Departures and Returns." Writers in East-West Encounters: New Cultural Bearings. Ed. Guy Amirthanayagam. London \& Basingstoke: Macmillan, 1982. 
—. The Lagoon and Other Stories. 1951. London: Bloomsbury, 1997.

—. Living in the Maniototo. 1979. London: The Woman's Press, 1996.

-. Owls Do Cry. Christchurch: Pegasus, 1961.

—. Prizes: Selected Short Stories. Auckland: Random House New Zealand, 2009.

—. The Reservoir and Other Stories. 1963. New York: George Braziller, 1993.

—. Snowman, Snowman: Fables and Fantasies. 1962. New York: George Braziller, 1993.

—. A State of Siege. 1966. New York: George Braziller, 1980.

Gordon, Pamela, and Denis HAROLD, eds. Dear Charles Dear Janet. Frame and Brasch in Correspondence. Auckland: Holloway Press, 2010.

MerCer, Gina. Janet Frame: Subversive Fictions. Dunedin: University of Otago Press, 1994.

RiCHARDS, Ian. "Janet Frame's Songs of Innocence and Experience: 'A Note on the Russian War'." Studies in the Humanities 58.3 (2007): 125-136.

Rutherford, Anna. "Janet Frame's Divided and Distinguished Worlds." The Ring of Fire: Essays on Janet Frame. Ed. Jeanne Delbaere-Garant. Mundelstrup \& Sydney: Dangaroo, 1992. 41-53.

SuZukI, Daisetz Teitaro. An Introduction to Zen Buddhism. Foreword by Carl Jung. New York: Grove Press, 1964.

WaTTS, Alan W. The Way of Zen. New York: Random House, 1957. 